\title{
The Influence of Internet on the Life and Ministry of the Spiritual Leaders in India
}

\author{
Thomas $\mathrm{MJ}^{1}$, Avinash De Sousa ${ }^{2}$ \\ ${ }^{1}$ PhD Scholar, Department of Psychology, Assam Don Bosco University, Guwhati. \\ ${ }^{2}$ Consultant Psychiatrist and Founder Trustee, Desousa Foundation, Mumbai. \\ E-mail - mjtomssp@gmail.com \\ Corresponding Author - Thomas MJ
}

\begin{abstract}
The invention of computer and internet has brought about dramatic changes in the way we think, speak, act and interact. It has become almost impossible to think of a society free of internet. While it can change our life for better, it can also influence our life and relationships negatively. Problematic internet use is a growing social issue which is being debated worldwide today. And it influences people of all walks of life. The paper aims at providing an overview on the use of internet among the spiritual leaders in India. On the basis of the interactions with the clergy in India and observations made on them together with the available literature, the author assumes that the spiritual leaders of different religions in India are exposed to the internet and influenced by it like the rest of the world. While internet makes significant positive contribution to their personal life and public ministry, the clergies are not spared from the ill-effects of the internet; some even becoming internet addicts.
\end{abstract}

Key words: internet, internet addiction, influence, spiritual leaders.

(Paper received $-14^{\text {th }}$ December 2017, Peer review completed $-30^{\text {th }}$ December 2017)

(Accepted $-30^{\text {th }}$ December 2017)

\section{INTRODUCTION}

We live in a technologically advanced and well-developed world. Our personal, family and societal life have been immensely influenced by the changes in the technology. It has influenced the way we think, live, learn, communicate, travel, purchase our products, etc. [1]. With the change in the technology and life style, there is also the increasing demand for advanced technology.

One of the main reasons for the advancement in life style and technology is the launch of the Internet and the many applications and possibilities that the Internet provides to the modern world. Internet makes possible the delivery of information instantaneous, continuous, and limitless [2]. It makes life easy for people to live in this complex era. Fast and innovative changes are taking place in the world because of the presence of internet, social media and mobile phones [3]. Everything is possible at the finger tips and there is so much fun in the world of Internet. Even the most tiring and physically challenging tasks are made comparatively easy with the arrival of the Internet.

It won't be wrong to say that internet has revolutionized the world of computers and communications like never before [4]. Internet has numerous possibilities to improve our life in the areas of communication, information, education, entertainment, business, etc. It enables collaboration between individuals irrespective of the geographical distances. But if not used judiciously it can lead to many destructive behaviours. One should be cautious about the unhealthy and inappropriate sites and materials that are 
easily available on the Internet that can damage life, family, profession, etc. Besides, there are also a lot of misinformation, and security threats to the lives of people [5].

This paper looks at how internet influences the spiritual leaders of the country and what impact it has on their spiritual life, communication, relationships, ministry, health, relaxation, etc.Deb [4] claims that "the influence of information technology on religious practices has mainly been to the effect of making information about them more accessible" [p.no.25]. It's a big challenge for all internet users to make the right choices and judicious use of the internet. This article tries to throw some light on addiction, spirituality and the possible impact of internet, both constructive and destructive, in the life of the spiritual leaders in India.

\section{WHAT IS INTERNET?}

It's difficult to give a definition to Internet since internet means differently to different people and encompasses a wide variety of services. Internet is the short form of "International Network". According to Instructional Software Research and Development (ISRD), Internet is "An ever growing wide area of network of millions of computers and computer networks across the globe which can exchange information through standard rules (protocols)" [6,p.no.2].

Internet is not a recent innovation. The essence of it has been around for over a quarter century. Internet comes into form by the global interconnection of hundreds of computers, communication entities and information systems [6]. By connecting to our PCs, laptops, mobile phones, robots, home appliances, etc., the Internet makes it easy and more user friendly.

\section{SPIRITUALITY AND ITS DEVELOPMENT}

Sheldrake [7] stated that the word spirituality originated in Christianity with the Latin adjective spiritualis, or 'spiritual'. The 'spiritual' then was not the opposite of 'bodily' or 'physical' but eventually it came to be considered so; i.e., contrary to God's spirit. According to him, "Spirituality' is a word that, in broad terms, stands for lifestyles and practices that embody a vision of human existence and of how the human spirit is to achieve its full potential. In that sense, 'spirituality' embraces an aspirational approach, whether religious or secular, to the meaning and conduct of human life" [7,p.no.1].

According to Sammarco [8], religion is a spiritual path and a true spiritual teacher is a person "who will encourage you on your path in life, demonstrate the path in their own lives, and encourage you to go out of the box in your search for truth" [p.no.3]. A spiritual person seeks to live under the guidance of God, whereas a worldly/fleshly person is more concerned with personal satisfaction and comfort.The contrast between these two-spiritual and worldly-remained common until a very important intellectual shift in Europe in the Middles Ages. During the Middle Ages, the noun 'spirituality' generally referred to the clergy. During the $17^{\text {th }}$ century, it came to refer to the spiritual life of people [7].

Spiritual growth of a person is not about meditating the complete time. "It's about real people leading dynamic and satisfying lives, and having the tools to help them through when the going gets tough" [9,p.no.2]. It's about living a life better than before, and enjoying it more. It involves wholesomeness and personal empowerment which will create a tendency in us to help others. We will go through an experience of healing and transformation. Although obstacles will be there, we will have the right tools to handle them.

The spiritual interests of people keep changing as times and seasons change. In the statistics of 2010 provided by Johnson and Grim [10] there are over 2.2 billion Christians, 1.5 billion Muslims, 948 million Hindus, 494 million Buddhists, 23 million Sikhs and 14 million Jews in the world besides other traditional faiths and the New Age movements. Yet in the midst of expanding spiritual interests, there is so much of war and violence in the world. Whereas what we long for is a spirituality that will bring people together and enable them to live in peace and harmony.

Contemporary interest in spirituality is part of a broader process of cultural change during the late $20^{\text {th }}$ century. Many people are not able to find solace in the traditional religions and therefore began to look for new sources of self-orientation. Thus spirituality became an "alternative way of exploring the deepest self 
and the ultimate purpose of life" [7,p.no.6]. It is a holistic approach-a spirituality with a fully integrated approach to life and it helps us to understand our identity and personality.

Today, spirituality is even contrasted with religion. A study conducted in North-West England by Paul Heelas and Linda Woodhead [11]) discovers that spiritualities which involve with personal experiences are far more acceptable than religions that demand conformity to higher truth. In the changing scenario, sensitivity to inner life and well-being is more important than mere conformity to external obligations. The contemporary spirituality desires a spiritual path that "reflects our present time and one in which the heart of religion is laid bare". It seeks a spirituality that fits the ever evolving world [12].

\section{DEFINITION OF ADDICTION}

Problems related to addiction have increased the social, economic and political challenges in our society along with serious physical and psychological problems at home, school, and work places. May states that "we are all addicts in every sense of the word" [13,p.no.4). According to him, "Addiction is any compulsive, habitual behavior that limits the freedom of human desire. It is caused by the attachment, or nailing, of desire to specific objects" [13,p.no.24-25]. People could be addicted to anything. It could be eating, exercising, having sex, shopping, working or even indulging in different hobbies [14]. Mosby's Paramedic Textbook defines addictions as a "compulsive, uncontrollable dependence on a substance, habit, or practice to such a degree that cessation causes severe emotional, mental, or physiological reactions" $[15$, p.no.24).

\section{DEVELOPMENT OF ADDICTION}

There are different factors that contribute to the development of addiction. The pattern of development into internet addiction can be similar to that of other addictions. Some of the prominent factors that influence the development of addiction are genetics factors, environmental factors and psychological factors.

\section{Genetic Factors}

People with certain genes find it hard to quit addiction once they start. Study by Agrawal and Lynskey [16] posits that genetic factors account for about half of the likelihood that an individual will develop addiction. If someone in the family has had problem with addiction, there is greater likelihood that others in the family will develop addiction in comparison to a person with no family history of addiction. Children of addicted parents, even when they are adopted continue to have increased risk of developing addiction [17]. History of multigenerational addiction can increase someone's risk 4 to 5 times in comparison to the general population [18].

Addiction, according to Koob, Arends and Moal [19], is a brain disease that afflicts millions of individuals all over the world. Some individuals with a genetic disposition that lacks enough dopamine receptors in the brain will engage in behaviors to raise the dopamine level in order to experience pleasure. Such behaviors can eventually become addictive [20]. Physiological changes due to the production of dopamine in the brain can lead a person into heightened use of Internet [21]. Similar to substance abuse, internet addiction also can be the result of lack of dopamine reward mechanisms [22].

\section{Environmental Factors}

Neuroscientists inform that the risk factors of addiction in our general population is half genetic and half environment. Kumpfer [23] states that children of addicted parents display greater likelihood to become alcohol and drug abusers due to both genetic and family environmental factors. Earlier a person begins alcohol or drug use the more likely he or she becomes addicted to alcohol or drug. Families with serious conflict, violence either physical or emotional, poor understanding among members, isolation experienced by the members, work pressures and stress, financial and marital problems, etc. can cause addiction in the families [24]. Peer pressure is another important reason for addiction [18]. 
Stressful life events can lead to problematic Internet use among adolescents [25-26]. Besides stressful life events, one's personality traits, psychological symptoms and family functioning are closely connected to Internet addiction [27-28-29]. An association is found between job strain and internet addiction. Job stress can lead to depression and anxiety which can cause behavioural addictions like internet addiction or substance addictions [30].

Caring and supportive environment can reduce the risk factor of addiction among children. Family affective involvement lowers the temperament and internet addiction while lack of affective involvement increase the temperament and the internet addiction [31]. Protective factors such as affective involvement of the parents, quality of the relationship between parents and youths, parenting attitudes, family communication, family cohesion and family violence exposure are associated with internet addiction [32].

\section{Psychological Factors}

Some of the psychological causes of addiction appear to stem from trauma, particularly when the addict is young. Research findings reveal that some of the risky personality traits such as neuroticism, psychoticism and immaturity are factors leading to internet addiction [33-34]. Psychologists propose several possible causes of addiction. 1) harmful behaviours are because of their abnormality or psychopathology; 2) people learn unhealthy behaviour by way of responding to the environment; 3 ) the feelings are the result of their thoughts and beliefs and if these thoughts and beliefs are dysfunctional, it is likely that their behaviour also will be negative [35].

Some researchers [36-37] claim that the internet addiction is correlated with social anxiety disorder, impulse control disorder, depression, mental health issues and attention deficit hyperactivity disorder. A meta-analysis study found a significant association between internet addiction and alcohol abuse, attention deficient hyperactivity disorder, anxiety and depression [38].

A qualitative study claims that the causes for intensive internet use are sadness, depression, boredom and stress [39]. People who are depressed have higher rate of internet use [40]. Managing and directing one's thoughts and emotions will basically decide the plausibility of internet addiction. Researchers studied the connection between internet addiction and impulse control and found that impulsivity is a marker for vulnerability to internet addiction [41].

Researchers have found a positive correlation between loneliness and internet addiction: "loneliness was the most important factor affecting Internet addiction" [42,p.no.316]. People who are lonely are more likely to use internet because of their social inhibitions and anxiety [43].

\section{INTERNET AND RELIGIONS}

Internet has influenced religions and spirituality in many different ways. The new generation is looking for a change from the routine spiritual practices. People like George Barna [44] foresee millions of people dropping out of religious organizations in order to join new forms like internet for worship and inspiration. As we go through the process of internet reformation, some scholars raise concerns about the possibility of internet drawing people away from spirituality because of the speed, vastness and surface-level materials available on the internet [45].

\section{Internet Use among Religions and Religious Leaders}

Within our current social climate, it is important to consider the effects of internet on different religions both traditional and liberal. Over the years, religious communication grew online and more online religious activities began to happen. Today different faiths or religions like Christianity, Judaism, Islam, Buddhism, Hinduism, and Paganism have their online presence.

The Pew report [46] of 2000 proves how religions, like the rest of the society, took advantage of the easy access, speed and low cost of the internet to communicate among the clergy and their congregations. It became so easy to connect with people all over the world. Internet makes it possible to send and receive information on one's religion and that of the others. The Pew reports [45-46] claim that there is a substantial increase in the successive surveys in the use of internet among religious followers and how it 
has helped them to stay connected and engaged with their church communities. However, adapting to the challenges of the internet has not been easy for all the religions [47].

Groothuis [48] tells what responsible Christian scholars should do in the analysis of the computermediated forms of communication: "Those who hold a Christian worldview need to discern the nature and function of cyberspace interactions in order to appraise rightly their significance, worth, and potential for the Christian cause and the culture at large" [p.no.631).Similarly Hinduism has anticipated many of the internet's most characteristic features in their religion. There have been "overwhelming amount of anecdotal and circumstantial evidence to suggest that Hindus have been particularly conscientious in mobilizing members of the perceived Hindu community through the internet" [49].Agboola [50] opines that the Muslims should work together to share information about Islam on the internet. "The future of Islamic propagation of the Internet is promising... Therefore, Muslims must develop and equip themselves with the tools of this future medium of communication" [p.no.19]. Internet has significant influence on the identity, authority and community of Buddhists. Looking at some of the contemporary online Buddhist practices, one would get some important insights into the shifting rolereligion plays in our constantly changing culture [51].

Although religious groups in the past have been sceptical and resistant to technological innovations, today many religions and religious leaders use new technologies as much as the general population. Pew report [45] states that $64 \%$ (128 million) of U.S. internet users have done things online that related to religious or spiritual matters. This figure is substantially higher in comparison to earlier researches by the same center. Larsen reports that the "The internet is being used by congregations to strengthen the faith and spiritual growth of their members, evangelize and perform missions in their communities and around the world, and perform a wide variety of pious and practical activities for their congregations"[46,p.no.2]. Many members feel that the internet has helped these faith communities to become better places. A report by Time magazine posits that religions are rushing onto the internet due to the routine traditional religious activities and the desire for the missionaries to look for new and creative means in the practice and spread of the faith [52].

According to Griffin, "Priests and vowed religious are at least as susceptible to the grip of addiction as laypeople, and although they may be more reluctant to accept help, they have an excellent success rate if they complete treatment that respects their vocational call" [53,p.no.14a]. Barna Research Group claims that nine out of ten Senior Pastors use a computer at home or at the church [44]. Study by Fukamizu [47] on religious specialists and followers in Japan infers that in postmodern faith, horizontal interaction that internet provides among religious groups and followers will play an increasingly important role in comparison with the vertical (top-down) structure of traditional doctrines. Kluver and Cheong suggests that "various religious communities have adopted and in some cases even embraced the Internet as part of their contemporary religious mission and strategy for growth" [54,p.no.1138]. The study examined the ways in which technological modernization and religion co-exist and even mutually reinforce one another.

\section{Paradigm Shift due to Internet}

The most useful gift of the modern world to humanity is the internet because it helps us with different areas of our life. Our everyday life activities like shopping, travelling, communication, etc. have become internet related. For example, today when we want to buy a book or a computer or a house, we immediately look up on the internet sites that provide us with various options of different ranges, and we can do all these sitting in the comforts of our room.

Internet also provides a wide range of knowledge on any subject under the sun, helps us with research and shares information to all professional fields. Bidgoli in The Internet Encyclopedia states that the "Internet and its associated technologies allow people to be creative, to express their individuality, and to communicate and connect with other individuals in new ways and with new freedom" [55,p.no.490].

\section{CONSTRUCTIVE IMPACTS OF INTERNET ON SPIRITUAL LEADERS}

Today more and more religious leaders and institutions are using internet and internet provided facilities to propagate their faith and religion. The Catholic Church feels that the internet and media when properly 
utilized, "can be of great service to mankind, since they greatly contribute to men's entertainment and instruction as well as to the spread and support of the Kingdom of God" [56,no.2].Internet impacts positively on the life and mission of the religions and religious leaders.

\section{Study of Faith and Religion}

Internet has far-reaching influence on all areas of life including religion and spirituality. People around the globe are exploring internet in order to access materials on faith, religion and related themes. A survey report of 2000 among 471 rabbis and ministers in the United States reveals that $77 \%$ sought information on the Bible, Torah or other scriptures, 59\% accessed information on doctrine, $57 \%$ got information on other denominations and faiths and 54\% sought information on matters of faith [46]. Majority of the priests I know use internet in order to access the updates on the teachings of the Church, daily reflections and prayers, study various religions and to share inspiring thoughts and messages. The Pew report showed that the internet was used by congregations to "strengthen the faith and spiritual growth of their members, evangelize and perform mission in their communities around the world, and perform a wide variety of pious and practical activities for their congregations" [46,p.no.2].

\section{Access to Information, Documents and Messages}

Internet provides useful information for people of all ages and professions. Hargittai [57] speaks about the wide range of information available on the internet covering various aspects of the society. Pope John Paul II [58] considered internet as a provider of "countless sources of information, documentation and education about the Church, her history and tradition, her doctrine and her engagement in every field in all parts of the world." Pew report [45] finds that internet is a "source of information, symbolic resources, and opportunities for networking and interaction outside the boundaries of formal religious bodies or traditions" [p.no.ii].Another Pew report [46] informs that "a striking number of the clergy have turned to the Internet to get material for sermons, worship, education programs, and matters of doctrine" [p.no.4]. Among the respondents $72 \%$ gathered information for educational programs. Many of the priests use internet as a platform to display information about their faiths and sacraments, staff and members and various activities undertaken by the institutions.

\section{Improves Creativity and Vitality in Worship}

Internet has brought about more creativity and vitality into worship. It helps traditional religions like Christianity which believes in gathering together in communion in order to remember, reflect, celebrate and witness God's love for His followers. Pope John Paul II [59] exhorted the Church "to be bold and creative" in using the media. "The Church would feel guilty before the Lord if she did not utilize these powerful means" [60,no.45]. Pope added that the creative use of internet can stir interest in individuals particularly the youth to actively participate in the worship. Internet helps the members to stay engaged with their religious communities and with their neighbourhood. Survey reveals that $81 \%$ of the participants accessed internet for information for worship and services, and $72 \%$ got devotional resources from the internet [46].

\section{Strengthens Communication and Relationships}

With internet at the fingertips, members and communities feel closer to one another. Parks and Roberts [61] opine that internet helps increased communication with family, friends, co-workers and even strangers in distant places and different cultures without time constraints. Those who use internet frequently might probably have more active social lives than those who do not use [62].

Internet provides new ways to communicate among the clergy, between clergy and their congregations. Pew report [46] posits that $33 \%$ of the respondents used internet to discuss matters on faith with others. A lot of clergy use internet to widen their contact, maintain quality relationships and to strengthen the ministry. It helps them to stay connected with their authorities, confreres, parishioners, family and friends. The speed and the easy access save a lot of time and energy in sharing information with the congregation.

\section{Provides Entertainment and Relaxation}


Internet today is the biggest and largest sources of entertainment. There are variety of online entertainment games that can be accessed anytime from anywhere. Study by Whittyand McLaughlin [63] posits that those who scored higher on loneliness and self-efficacy were more likely to use the internet for computerbased entertainment and to facilitate offline entertainment. Internet is a good tool for the clergy to relax from their daily stress, loneliness, boredom and other problems. Internet also helps the clergy to communicate with friends and dear ones through different social networking sites and to seek timely support and guidance especially when one feels lonely and stressed out. The availability of number of online songs, videos, comics, films, etc. can be of great help in times of distress.

\section{ADVERSE INFLUENCES OF INTERNET ON SPIRITUAL LEADERS}

No scientifically documented findings could be obtained with regard to the adverse influences of internet on spiritual leaders. The below assumptions are based on my personal observations, interviews and interactions among the clergy in India.

\section{Decline in Spiritual Well-being}

It's important to note that while "internet offers extensive knowledge, but it does not teach values; and when values are disregarded, our very humanity is demeaned and man easily loses sight of his transcendent dignity" [58,p.no.4]. It is observed that the spiritual life of some of the clergy is negatively affected by the over use of internet. Several hours spent on social networking, watching movies and videos can take one's focus away from prayer affecting the rhythm of life. To spend more time online, one neglects his spiritual obligations and finds less time for reading the Bible, meditation and reflection. He gets distracted during prayer thinking of his online activities. Spiritual practices can become routine services lacking soul due to overuse. Internet can influence one's values of honesty and sincerity. Watching of unhealthy materials can lead to distractions and guilt.

\section{Irrational Thinking}

Internet influences the way we think and interact. Research by Granicand Lamey [64] explains how internet influences one's critical thinking and cognitive flexibility. Internet causes a shift from essentialist thinking to a sense of perspectivism. Some religious leaders have raised concerns about the improper use of internet. They warn the users regarding the potential effects of internet on one's ability to think. The flood of information on internet will reduce the need for reflection. It will aggravate the existing inequalities in the society. Internet tempts to look for what is "tangible, useful and instantly available; the stimulus for deeper thought and reflection may be lacking" [58,no.4]. Some of the priests confess that internet corrupts their minds and affects their critical thinking. It increases the tendency to copy materials indiscreetly giving way to original thinking and creativity. It reduces their intelligence. Some confess that they share information without verifying the facts. Although internet gives answers to many questions on religions, it does not give us the reasoning behind the answer, and may not challenge us to think.

\section{Negligence of Duty}

Internet overuse can negatively affect someone's efficiency at work. Study by Nalwa and Anand [65] found that internet dependents would delay their work because of the time spend on the internet. There is a positive correlation between internet addiction and academic and general procrastination [66]. Some clergy do feel that internet makes them indifferent to the way of life they have chosen and it takes their focus away from their duties and responsibilities. It affects their attention makes them victims of procrastination. There are others who waste a lot of time browsing internet for unproductive activities neglecting their duties. Overuse of internet reduces one's love for Holy Mass and sacraments. Late night browsing leads to sleep, lethargy and exhaustion during the day.

\section{Uncommitted Relationships}

Internet has affected the quality and commitment to relationships. Internet addiction can affect one's relationships, vocation and marriage [67]. Researchers find negative effect of internet addiction on family 
relations [68]. Virtual relationships are taking the place of face-to-face personal interactions. The increase in the number of online relationships have adverse effect on existing face-to-face relationships. Many of these relationships are romantic in nature [69]. Since the arrival of the internet, the world of interaction, involvement and outreach have been reduced. Religious leaders caution the people that "electronically mediated relationship can never take the place of the direct human contact required for genuine evangelization" [58,no.5]. Internet causes superficial relationships among the spiritual leaders as well. Clergy seem to develop more virtual friends affecting committed relationships. They report that it has negatively affected community building. Internet has taken the place of community recreations and group chats in parishes and religious houses.

\section{Health Hazards}

Excessive internet use can have lasting consequences on one's health. Overuse of computer denies one the possibility of exercise and can lead to high risk for carpal and radial tunnel syndrome, back pain, eye strain, obesity and sleep disorders [70]. To spend long time on the internet one will forego some required sleep, even staying up until morning. Some clergy admit that internet has even affected their proper food intake and relaxation. A few report back pain and eye pain due to long hours of internet use.

\section{CONCLUSION}

To conclude, the study looks at how internet addiction is similar to other addictions. It highlights how the spiritual leaders in our country are much like the general population in the use of the internet. While they enjoy the benefits of the internet, they are not spared from theproblems that the ordinary people face in their day today lives. The study throws some light on how internet influences their prayer life, health, relationships, relaxation and thought. Easy access to information and faster communication have certainly made the life and ministry of religious leaders more relevant and fruitful. It's a challenge for all to make the right and judicious use of the internet in this era of internet revolution.

It is an undisputable fact that the growth in the field of the Web and the Internet is ever-growing and ever changing, and it will continue to grow and transform the world of telecommunications and influence all areas of human life for the centuries to come. As to the future of the Internet, it will have to face a lot of new technical and social challenges. Abbate observes, "If the Internet is to continue as an innovative means of collaboration, discovery, and social interaction, it will need to draw on its legacy of adaptability and participatory design" [71,p.no.220].

\section{REFERENCES}

1. Greenfield DN. Virtual Addiction: Help for Netheads, Cyberfreaks, and Those Who Love Them. California: New Harbinger; 1999.

2. Adams J, Blau J. Job Surfing: Media and Entertainment. New York: Random House, Inc.; 2002.

3. Biagi S. Media/Impact: An Introduction to Mass Media. $10^{\text {th }}$ ed. United States: Wadsworth, Cengage Learning; 2011.

4. Deb S. Information Technology, Its Impact on Society and Its Future. Advances in Computing 2014;4(1):2529.

5. Buckley P, Clark D. The Rough Guide to the Internet. 14 ${ }^{\text {th }}$ ed. London: Penguin Books Ltd.; 2009.

6. Instructional Software Research and Development (ISRD) Group. Internet Technology and Web Design. New Delhi: Tata McGraw Hill Education Private Limited; 2011.

7. Sheldrake P. Spirituality: A Very Short Introduction. United Kingdom: Oxford University Press; 2012.

8. Sammarco SD. I'm Not Religious. I'm a Spiritual Person: Inspiration and answers for those on a spiritual path. Durham (CT): Strategic Book Group; 2011.

9. Durga S. Ignite Your Spirit: What is Spirituality and How Do You Feel Great? $3^{\text {rd }}$ ed. Australia: Higher Guidance Pty Ltd.; 2010.

10. Johnson TM, Grim BJ. The World's Religions in Figures: An Introduction to International Religious Demography. UK: Wiley-Blackwell; 2013. 
11. Heelas P, Woodhead L. The Spiritual Revolution: why religion is giving way to spirituality. USA: Blackwell Publishing; 2005.

12. Christi N. Contemporary Spirituality for an Evolving World: A Handbook for Conscious Evolution. Vermont: Bear \& Company; 2013.

13. May GG. Addiction and Grace: Love and Spirituality in the Healing of Addictions. New York: Harper One; 1988.

14. Mihordin R. Behavioral addiction - Quo Vadis? J. NervMent Dis 2012;200:489-491.

15. Sanders MJ. Mosby's Paramedic Textbook. United States of America: Mosby; 2012.

16. Agarwal A. Lynskey MT. Are there genetic influence on addiction: evidence from family, adoption and twin studies. Addiction 2008;103:1069-1081.

17. Schuckit MA, Goodwin DA, Winokur G. A study of alcoholism in half siblings. Am J Psychiatry 1972;128:1132-1136.

18. Marion NE, Oliver WM, eds. Drugs in American Society: An Encyclopaedia of History, politics, Culture, and the Law. $1^{\text {st }}$ Ed. California: ABC-CLIO; 2015.

19. Koob GF, Arends MA, Moal ML. Drugs, Addiction, and the Brain. Amsterdam: Elsevier; 2014.

20. Beard KW. Internet Addiction: A Review of Current Assessment Techniques and Potential Assessment Questions. CyberPsychology\&Behavior2005;8(1):7-14.

21. Bai YM, Lin CC, Chen JY. Internet addiction disorder among clients of a virtual clinic. Psychiatric Services 2001;52(10):1397.

22. Weinstein A, Lejoyeux M. New Developments on the Neurobiological and Pharmaco-Genetic Mechanisms Underlying Internet and Videogame Addiction. Am J Addict 2015;24:117-125.

23. Kumpfer KL. Outcome measures of interventions in the study of children of substance-abusing parents. Pediatrics 1999;103(5):1128-1144.

24. Guebaly N, Offord DR. The offspring of alcoholics: a critical review. Am J Psychiatry 1997; 134(4):357-365.

25. Li DP, Zhang W, Li XA, Zhen SJ, Wang YH. Stressful life events and problematic Internet use by adolescent females and males: A mediated moderation model. Computers in Human Behavior 2010;26(5):1199-1207.

26. Li H, Wang J, Wang L. A survey on the Generalized Problematic Internet Use in Chinese College Students and its Relations to Stressful Life Events and Coping Style. Int J Ment Health Addict 2009;7(2):333-346.

27. Yan W, Li Y, Sui N. The Relationship between Recent Stressful Life Events, Personality Traits, Perceived Family Functioning and Internet Addiction among College Students. Stress Health 2014;30(1):3-11.

28. Tang J, Yu Y, Du Y, Ma Y, Zhang D, Wang J. Prevalence of internet addiction and its association with stressful life events and psychological symptoms among adolescent internet users. Addictive Behaviors 2014;39(3):744-747.

29. Yang L, Sun L, Zhang Z, Sun Y, Wu H, Ye D. Internet addiction, adolescent depression, and the mediating role of life events: finding from a sample of Chinese adolescents. Int J Psychol2014;49(5):342-7.

30. Chen SW, Gau SF, Pikhart H, Peasey A, Chen ST, Tsai MC. Work Stress and Subsequent Risk of Internet Addiction Among Information Technology Engineers in Taiwan. CyberpsycholBehav and SocNetw 2014;17(8):542-550.

31. Pace U, Zappulla C, Guzzo G, Di Maggio RS, Laudani C, Cacioppo M. Internet Addiction, Temperament, and the Moderator Role of Family Emotional Involvement. Int J of Ment Health Addict 2014;12:52-63.

32. Park SK, Kim JY, Cho CB. Prevalence of internet addiction and correlations with family factors among South Korean adolescents. Adolescence 2008;43(172):895-909.

33. Dong G, Wang J, Yang X, Zhou H. Risk personality traits of Internet addiction: A longitudinal study of Internet-addicted Chinese university students. Asia Pac Psychiatry 2012;5:316-321.

34. Phillips GT, Gossop M, Bradley B. The influence of psychological factors on the opiate withdrawal syndrome. Br J Psychiatry 1986;149(2):235-238.

35. Horvath AT, Misra K, Epner AK, Cooper MG. Psychological Causes of Addiction. MentalHelp.net 2016, March 14; Retrieved from: https://www.mentalhelp.net/articles/psychological-causes-of-addiction/

36. Yen JY, Yen CF, Chen CS, Tang TC, Ko CH. The association between adult ADHD symptoms and internet addiction among college students: the gender difference. Cyberpsychology\&Behavior 2009;12(2):187-191.

37. Cao F, Su L, Liu T, Gao X. The relationship between impulsivity and Internet addiction in a sample of Chinese adolescents, European Psychiatry 2007;22(7):66-471.

38. Ho RC, Zhang MW, Tsang TY, Toh AH, Pan F, Lu Y, et al. The association between internet addiction and psychiatric co-morbidity: a meta-analysis. BMC Psychiatry 2014;14:183.

39. Li W, O'Brien JE, Snyder SM, Howard MO. Characteristics of Internet Addiction/Pathological Internet Use in U.S. University Students: A Qualitative-Method Investigation. PLoS ONE 2015;10(2):e0117372. 
40. Özcan NK, Buzlu S. Problematic Use of the Internet is a Tool to Help Determine the Scale of Cognitive Status on the Internet, the Reliability and Validity of the University students. Journal of Addiction 2005;6(1):19-26.

41. Lee HW, Choi JS, Shin YC, Lee JY, Jung HY, Kwon JS. Impulsivity in Internet Addiction: A Comparison with Pathological Gambling. CyberpsycholBehav and SocNetw 2012;15(7): 373-377.

42. Bozoglan B, Demirer V, Sahin I. Loneliness, self-esteem, and life satisfaction as predictors of Internet addiction: A cross-sectional study among Turkish university students. Scand J Psychol 2013;54:313-319.

43. Solano C, Koester N. Loneliness and Communications Problems: Subjective Anxiety or Objective Skills? Personality and Social Psychology Bulletin 1989;15(1):126-133.

44. Barna Research Group. More Americans Are Seeking Net-Based Faith Experiences. 2001, May 21. Retrieved on 29 November 2017from https://www.barna.com/research/more-americans-are-seeking-netbased-faith-experiences/

45. Hoover SM, Clark LS, Rainie L. Faith online. Pew Internet \& American Life Project. 2004. Retrieved on November 27, $2017 \quad$ from http://www.pewinternet.org/files/oldmedia/Files/Reports/2004/PIP Faith Online 2004.pdf.pdf

46. Larsen E. Wired churches, wired temples: Taking congregations and missions into cyberspace, Pew Internet \& American Life Project: Online life report. 2000 December. Retrieved on 27 November 2017 from http://www.pewinternet.org/files/old-media/Files/Reports/2000/PIP Religion Report.pdf.pdf

47. Fukamizu K. Internet Use Among Religious Followers: Religious Postmodernism in Japanese Buddhism. Journal of Computer-Mediated Communication 2007;12(3):977-998.

48. Groothuis D. Christian Scholarship and the Philosophical Analysis of Cyberspace Technologies. JETS 1998;41(4):631-640.

49. Lal, V. When Hinduism meets the internet. 2013, January 20. The Times of India. Retrieved on 11 December 2017 from https://timesofindia.indiatimes.com/home/sunday-times/all-that-matters/WhenHinduism-meets-the-internet/articleshow/18097148.cms

50. Agboola AK. Religious Communication and Internet Usage: How Do Muslims Fare on the Web? MiddleEast J Sci Res 2014;20:11-20.

51. Grieve GP, Veidlinger D, eds. Buddhism, the Internet, and Digital Media: The Pixel in the Lotus. New York: Routledge; 2015.

52. Ramo JC. Finding God on the Web: Across the Internet, Believers are Re-examining their Ideas of Faith, Religion and Spirituality. Time 1996, December 16. Retrieved on November 27, 2017 from http://www.time.com/time/archive/preview/0,10987,985700,00.html

53. Griffin B. Ministering to the ministers: Organizations take a spiritual focus when serving clergy, religious in mental health crises. National Catholic Reporter 2010;14a-15a.

54. Kluver R, Cheong PH. Technological Modernization, the Internet, and Religion in Singapore. Journal of Computer-Mediated Communication 2007;12(3):1122-1142.

55. Bidgoli H, ed. The Internet Encyclopedia: Volume 1, A-F. New Jersey: John Wiley \& Sons, Inc., 2004.

56. Pope Paul VI. Inter Mirifica. 1963 December 4. Retrieved on 12 December 2017 from http://www.vatican.va/archive/hist councils/ii vatican council/documents/vatii decree 19631204 inter-mirifica en.html

57. Hargittai E. Open Portals or Closed Gates? Channeling Content on the World Wide Web. Poetics 2000b;27:233-253.

58. Pope John Paul II. Internet: A New Forum for Proclaiming the Gospel. 2002 May 12. Retrieved on 30 November $2017 \quad$ from $\quad \underline{\mathrm{http}: / / \mathrm{w} 2 . v a t i c a n . v a / c o n t e n t / j o h n-p a u l-}$ ii/en/messages/communications/documents/hf jp-ii mes 20020122 world-communications-day.html

59. Pope John Paul II. Proclaiming Christ in the Media at the Dawn of the New Millennium. 2000 June 4. Retrieved on 14 December 2017 from http://w2.vatican.va/content/john-paulii/en/messages/communications/documents/hf_jp-ii_mes_20000124_world-communications-day.html

60. Pope Paul VI. EvangeliiNuntiandi 1975 December 8. Retrieved on 14 December 2017 from http://w2.vatican.va/content/paul-vi/en/apost_exhortations/documents/hf_p-vi_exh_19751208_evangeliinuntiandi.html

61. Parks MR, Roberts LD. Making Moosic: The Development of Personal Relationships on Line and a Comparison to their Off-Line Counterparts. J SocPersRelat 1998;15:517-537.

62. Robinson JP, Kestnbaum M, Neustadtl A, Alvarez A. Mass Media Use and Social Life Among Internet Users. SocSciComput Rev 2000;18(4):490-501.

63. Whitty MT, McLaughlin D. Online recreation: The relationship between loneliness, Internet self-efficacy and the use of the Internet for entertainment purposes. Comput Hum Behav2007;23(3):1435-1446. 
64. Granic I, Lamey AV. The self-organization of the Internet and changing modes of thought. News Ideas in Psychology 2000;18(1):93-107.

65. Nalwa K, Anand AP. Internet addiction in students: a cause of concern. Cyberpsychology\&Behavior 2003;6:653-656.

66. Uzun AM, Unal E, Tokel ST. Exploring Internet Addiction, Academic Procrastination and General Procrastination among Pre-Service ICT Teachers. MIJE 2014:4(1):189-201.

67. Young KS. Internet Addiction: The Emergence of a New Clinical Disorder. Cyberpsychology\&Behavior 1996;1(3):237-244.

68. Chou C, Condron L, Belland JC. A Review of the Research on Internet Addiction. EducPsychol Rev 2005;17(4):363-388.

69. Underwood H, Findlay B. Internet Relationships and Their Impact on Primary Relationships. Behaviour Change 2004;21(2):127-140.

70. Lam LT. Internet gaming addiction, problematic use of the Internet, and sleep problems: A systematic review. Curr Psychiatry Rep 2014;16(4):444.

71. Abbate J. Inventing the Internet. Massachusetts: The MIT Press; 2000.

$* * * * * * * * * * * * * * * * * * * * * *$

Acknowledgements - Nil

Source of Funding - Nil

Conflict of Interest - Nil 